Article Type: Research Paper

\title{
TECHNOLOGICAL PROGRESS AND HUMAN DEVELOPMENT: EVIDENCE FROM INDONESIA
}

\author{
M. Muchdie* and M. Nurrasyidin
}

\begin{abstract}
This paper examined direct and indirect impact of technological progress on human development, with income disparities and poverty as moderating variables. Except data on technical progress, all data were collected from National Statistics Agency. A path model of analysis was empolyed to examine direct and indirect impacts. There were four paths to be analysed: direct impact (Path-1: $\mathrm{P}_{41}$ ) and indirect impacts : (Path-2: $\mathrm{P}_{43} \times \mathrm{P}_{31}$, Path-3: $\mathrm{P}_{43} \times \mathrm{P}_{32} \times \mathrm{P}_{21}$ and Path-4 : $\mathrm{P}_{42} \times \mathrm{P}_{21}$ ). Four hypothesis had been tested. The results showed that impact of technological progress on human development were negative, both direct and indirect.
\end{abstract}

Universitas Muhammadiyah Prof. Dr. HAMKA. Jakarta. Indonesia.

\section{*CORRESPONDENCE:}

eidmuchdie@uhamka.ac.id

THIS ARTICLE IS AVALILABLE IN: http://journal.umy.ac.id/index.php/esp

Keywords: Human Development; Income Disparities; Poverty; Technological Progress.

JEL Classification: D63, I32, 015, 033.

DOI: 10.18196/jesp.20.1.5018

\section{CITATION:}

Muchdie, M. \& Nurrasyidin, M. (2019). Technological Progress and Human Development: Evidence from Indonesia. Jurnal Ekonomi \& Studi Pembangunan, 20(1), 99-111

\section{ARTICLE HISTORY}

\section{Received:}

September 2018

Accepted:

April 2019

\section{Introduction}

Human development is a concept in development that includes the study of the human condition. Human development is about efforts to expand the wealth of human life rather than enrich the economic life (Streeten, 1994). Human development is an alternative approach to the single focus of development, namely economic growth (Srinivasan, 1994). Human development focuses more on social justice as a way of understanding efficacy. The United Nations Development Program (1997) defines human development as a process of expanding people's choices that enable them to enjoy a long and healthy life, educated and have a decent standard of living.

Human development is measured by the human development index (HDI), which is a measurement of the comparison of life expectancy, literacy, education and living standards for all countries throughout the world. HDI is used to classify whether a country is a developed country, developing country or underdeveloped country and also to measure the influence of economic policy on quality of life (Davies \& Quinlivan, 2006). The HDI explains how people can access the results of development in obtaining income, health, education, and so on.

In 2015, Indonesia's HDI reached 69.55 from the 2015 State Budget target of 69.40. In the health dimension, the indicator is the community life 
expectancy, which in 2015 reached 70.78 years, rose 0.19 percent compared to 2014 . During the period 2010-2015, Indonesia succeeded in increasing the life expectancy at birth by 0.97 years. Furthermore, the dimensions of education are determined by indicators of school length expectations and average length of school. In 2015, the duration of schooling in Indonesia reached 12.55. That is, children aged 7 years have the opportunity to finish their education until graduating from high school or D-1. While the average length of school in Indonesia reached 7.84 . That number rose 0.11 from the figure in 2014, which was 7.73. The final dimension is the economic dimension, with indicators of decent living standards represented by the per capita expenditure of 2012 constant prices adjusted for purchasing power parity (Anonymous, 2016a).

Another variable that is strongly related to human development is poverty. Poverty is defined as a condition of inability to meet basic needs such as food, clothing, shelter, education, and health. Poverty can be caused by a scarcity of basic fulfillment needs, or difficult access to education and employment (Anonymous, 2016a). In the 2004-2009 Medium-Term Development Plan (RPJM), the government targeted the percentage of those living below the poverty line ${ }^{1}$ decrease from 17.42 percent in 2004 to 8.20 percent in 2009. In the 2010-2014 Medium-Term Development Plan (RPJM) the percentage of poor people was targeted at 8 percent in 2014 (Suryahadi, et al., 2010).

The problem of poverty is also related to the issue of income inequality. Income inequality is a condition where the distribution of income received by society is uneven. Inequality is determined by the level of development and ethnic heterogeneity. Inequality is also related to dictatorships and governments that fail to respect property rights (Glaeser, 2005). Poverty is closely related to the inequality of income distribution. If income distribution is uneven, it can certainly disrupt the economy, even leading to increased poverty. High economic growth but not accompanied by a level of income will still leave the number and percentage of poor people who will have an impact on health, education and purchasing power.

One of the most popular measures of inequality is the gini index (gini ratio), which is a measure of aggregate inequality whose values range between zero and one. The zero gini index value means there is no inequality, while the value of one means perfect inequality. This index is purely a statistical measure for variability and normative measures in measuring inequality. Historically, technology has played a central role in improving the living standards of citizens, including the poor. Green Revolution and various modern innovations in the field of health and medicine are important instruments in improving nutrition, health and life for millions of people. Agricultural biotechnology and medicine are very promising, even though risks still need to be taken into account before their full potential can be realized. New information technology is an initial diffusion, but the impact can be very deep for the lives of the poor, empowering them to achieve access to classified information is scarce (OECD \& ADB, 2002). Technological advances almost always have a positive impact on economic growth and increased income, but with

1 The poverty line is equivalent to 2100 calories per capita per day for the food and basic non-food consumption component. 
inequality in access to production, poverty remains. Ideally, technological progress will reduce poverty.

Human Development is an approach or model of development that focuses on people. UNDP (2015) emphasized that human development is a development approach that puts forward "human flourishing". Human development is a process of expanding people's choices that enable them to enjoy long and healthy, educated and decent lives (Anonymous, 2015). Thus, the three dimensions of human development are income as measured by purchasing power parity, health as measured by life expectancy, and education measured by the opportunity to obtain education and length of school.

Human development is measured by the human development index (HDI), which is a measurement of the comparison of life expectancy, literacy, education and living standards for all countries around the world. HDI is used to classify whether a country is a developed country, developing country or underdeveloped country and also to measure the influence of economic policy on quality of life (Davies \& Quinlivan, 2006). The HDI explains how people can access the results of development in obtaining income, health, education, and so on. IPM was introduced by (UNDP) in 1990 and published periodically in the annual report of the Human Development Report. The HDI is formed by 3 (three) basic dimensions: (1) long life and healthy life, (2) knowledge, and (3) decent living standards (Anonymous, 2014a).

Poverty is a condition where a person has a certain amount of material or money. According to Ricardo (2008), this is a face-to-face concept, which includes social, economic and political elements. Many definitions have been introduced, for example the most famous in the 1970 s was the Sayogyo ${ }^{2}$ poverty line which was equivalent to $240 \mathrm{~kg}$ of rice per capita per year, Suparlan (1984) with urban poverty, and Edi Suharto (2009). Poverty is the inability to have choices and opportunities, a violation of human excellence. This means that there is a lack of basic capacity to participate effectively in society. It also means that there is insufficient food and clothing, no schooling and medical treatment, no land for farming or employment to obtain income, nor does it have access to credit. That also means being insecure, having no power. It also means "susceptibility to violence" and often implies living in a marginal and vulnerable environment, without access to clean water and sanitation (Anonymous, 2016b).

At the same time, there are also those that define poverty as the low welfare of society and this includes many dimensions. That includes low income and the inability to obtain basic needs to survive by being successful. Poverty is also related to low levels of health and education, limited access to clean water and sanitation, vulnerable security, voices and insufficient capacity and opportunities for a better life (Anonymous, 2011).

Poverty can be defined as absolute poverty and relative poverty. Absolute poverty refers to a standard that is consistent over time and between countries. Absolute poverty is a

http://www.kompasiana.com/economist-suweca.blogspot.com/prof-sajogyo-dan-gariskemiskinan_55102882813311d138bc614b 
condition characterized by the absence of the availability of basic human needs such as food, healthy drinking water, sanitation facilities, health, shelter, education and information. Poverty depends not only on income, but also depends on access to services ${ }^{3}$. Absolute poverty is often interpreted as extreme poverty. Robert McNamara, former President of the World Bank, describes absolute poverty or extreme poverty as "a condition so limited by malnutrition, illiteracy, disease, squalid surroundings, high infant mortality, and low expectancy as to be beneath any reasonable definition of human decency"4.

First introduced in 1990, one dollar a day in measuring absolute poverty by the standards of the world's poorest countries. The World Bank set an international poverty line of \$ 1.25 per day in 2008 (which is equal to US $\$ 1.00$ per day in 1996). In October 2015, it was re-set to US $\$ 1.90$ per day ${ }^{5}$. The poverty line of US $\$ 1.90$ per day set by the World Bank is somewhat controversial because each country has its own boundaries for its absolute poverty line. For example, in the United States the poverty line is US $\$ 15.15$ per person per day in 2010 (US $\$ 22,000$ per year for families with 4 members) $)^{6}$, while in India the poverty line is US $\$ 1.0$ per person per day ${ }^{7}$, in Indonesia the poverty line is US $\$ 0.84$ per per people day ${ }^{8}$ and in China the absolute poverty line is US $\$ 0.55$ per person per day. All are based on purchasing power parity in $2010^{9}$.

Relative poverty views poverty as socially defined and depends on social contexts, poverty is a relative measure of income inequality. Usually poverty is relatively measured as the percentage of the income earner is less than a certain proportion of average income. There are several measures of income inequality such as the Gini Coefficient or Theil Index. Measures of relative poverty are used by UNDP, UNICEF, OECD and Canadian poverty researchers (Raphael, 2009; OECD, 2008; UNDP, 2008).

Various poverty reduction strategies are broadly categorized as whether the strategy provides more basic human needs or the strategy increases income that can be spent to buy the living needs of the poor. Some strategies such as road construction can not only provide access to a variety of basic needs, such as fertilizer from urban areas, but also increase income by bringing better access to urban markets. In the case of Indonesia, during the administration of President SBY (2004-2013) there were three clusters of poverty

3 UN Declaration at World Summit on Social Development in Copenhagen 1995.

4 Definition of poverty according to the World Bank... Retrieved 10 Augustus 2016.

5 The World Bank re-establishes the international poverty line to US\$1.90 per person per day, which has considered the difference in living costs between countries (exchange rates based on purchasing power disparities).

$6 \quad$ The definition of poverty according toUS Census Bureau. 2011.

7 Read: World Bank's $\$ 1.25 /$ day poverty measure- countering the latest criticisms. The World Bank. 2010.

8 For 2014, the Indonesian Government set a poverty line to Rp. 312,328, per person per month equivalent to US\$ 25 per person per month.

$9 \quad$ New Progress in Development-oriented Poverty Reduction Program for Rural China (1,274 Yuan per year = US\$̦ 0.55 per day). The Government of China. 2011. 
alleviation programs. First, the cluster of social assistance for poverty alleviation includes protection of consumption of basic commodities, health protection, education protection and protection of financial liquidity for the poor. Second, the community empowerment cluster for poverty alleviation. Third, the micro business empowerment cluster for alleviation (Suryahadi, et.al, 2010).

The relationship of poverty with human development includes three dimensions of the human development index. Poverty due to low income makes the level of health low due to the inability to obtain food including drinking water, clothing and shelter including healthy sanitation. Poverty also limits the ability of communities to be able to gain access to better education.

Income inequality is a condition where the distribution of income received by society is uneven. Inequality is determined by the level of development, ethnic heterogeneity, inequality is also related to dictatorships and governments that fail to respect property rights (Glaeser, 2005). Poverty is very closely related to the inequality of income distribution. If the income distribution is not evenly distributed, it can be certain that it will disrupt the economy, which can even lead to increased poverty. High economic growth but not accompanied by a level of income will still leave the number and percentage of poor people who will have an impact on health, education and purchasing power.

One of the most popular measures of inequality is the gini index (gini ratio), which is a measure of aggregate inequality whose values range between zero and one. The zero in dex value means there is no inequality (perfect equalization), while the value of one means perfect inequality. This index is purely a statistical measure for variability and normative measures to measure inequality. Wodon and Yitzaki (2002) revealed: .... the main advantages of the Gini Index, firstly, as a statistical measure for variability, the gini index can be used to calculate negative income, this is one of the traits that some inequality measures do not have. Second, the Gini index can also be described geometrically so that it is easier to observe and analyze, and thirdly, this index has a strong theoretical basis. As a normative index, the gini index can represent the theory of relative poverty. This index can also be derived as a measure of inequality based on the axioms of social justice.

The main problem in income inequality is due to differences in productivity possessed by each individual where one individual / group has higher productivity than other individuals / groups. The uneven distribution of income triggers income inequality which is the beginning of the emergence of the problem of poverty. Allowing these two problems will further aggravate the situation, and not infrequently cause negative consequences for the social conditions of the community. The inequality of income distribution and poverty is a reality that exists among the world community, both in developed and developing countries. The difference lies in the proportion of the level of inequality and the number of poverty that occurs, as well as the level of difficulty in overcoming it which is influenced by the area and the population of a country. Uneven distribution of national income will not create prosperity for society in general. A distribution system that is not pro-poor will only create prosperity for certain groups, so this becomes a very important issue in addressing the problem of poverty. According to Todaro and Smith (2002), the effect of 
income inequality on poverty is due to an increase in population. Population growth tends to have a negative impact on the poor, especially for those who are very poor. Most poor families have a large number of family members so that their economic conditions at the poverty line deteriorate along with deteriorating income or welfare inequality. The direct relationship between income inequality and human development has never been studied. At least, the publication has not been found.

Science and technology are identical and cannot be separated from human development. Technological advances, technological changes, technological development or technological achievements are the whole process of invention, innovation and technology diffusion. In essence, technological advances are inventions of technologies and their commercialization through research and development, continuous technological improvements and their diffusion to industry and society. In short, technological advances are based on better and more sophisticated technology. In economics, technological progress is a positive change in the production function that changes the relationship between input and output, which is generally understood as technological improvement or technological progress (Hicks, 1963). Productivity is a measure of technological progress. Productivity increases when fewer inputs are used in the production process (Field, 2008). Another indicator of technological progress is the development of new products and services needed to overcome labor shortages so labor costs are reduced. In developed countries generally productivity growth slowed in the late 1970s, but there are certain sectors that have better growth, such as in the industrial sector (Bjork, 1999).

Muchdie (2016) found that technological progress has a positive direct impact on poverty alleviation efforts in Indonesia. Indirectly, technological advances also have a positive impact on poverty alleviation through economic growth and unemployment. Unfortunately, there is no clear agreement about the relationship between technological progress and income inequality. There is no agreement if it is said that technological progress is the cause of income inequality. The reason, technology has made everything easier. Because the technological advancement of the world becomes a small village which means there is no distance between people. Everyone and income groups are able to buy technology to stay connected to each other. Technology is everywhere, in the garden or in the bank. Technology has created income with little investment. Technology is a special blessing for humanity, which makes work easier and more efficient. Conversely, some argue that technological progress is related to income inequality. Indeed, technology is important for human life, but because of the differences between rich and poor, skilled and unskilled, conditions vary. Further technological advancements will create income inequality. Technological progress has created income inequality between sectors and between groups, also between regions. However, technology is defined as the application of knowledge, tools, machines, techniques and systems or methods to deal with problems effectively and efficiently. Thus, the use of technology helps humans to achieve high efficiency in terms of speed, productivity and income. 
Applying path analysis method, this paper aims to analyze the direct and indirect impacts on technological advances in human development, with poverty and income inequality as a variable (moderating variables).

\section{Research Method}

The model used for analyzing the direct and indirect impacts of technological advances on human development is presented in Figure 1. Path analysis is used to analyze the direct and indirect effects of one variable on another. This model was developed by Wright in the 1920s (Wrigth, 1921; 1934). because it is widely used in more complex modeling such as in the fields of biology, psychology, sociology and econometrics (Dodge, Y, 2003). In this study the path model is used to answer the question, "how technological progress affects (index) human development?".

The direct impact of technological progress on human development was analyzed using Line-1, with path coefficient $P_{41}$. The indirect impact of technological progress on human development is explored through Path-2, which is hypothesized that technological progress has an indirect impact on human development, through the variable between poverty. The path coefficient on Path-2 is calculated as the multiplication of the direct effect of technological progress on poverty $\left(P_{31}\right)$ with the direct impact of poverty on human development $\left(\mathrm{P}_{43}\right)$. The indirect impact of technological progress on human development is also examined through Path-3, where technological advances have an indirect impact on human development through variables of poverty and income inequality.

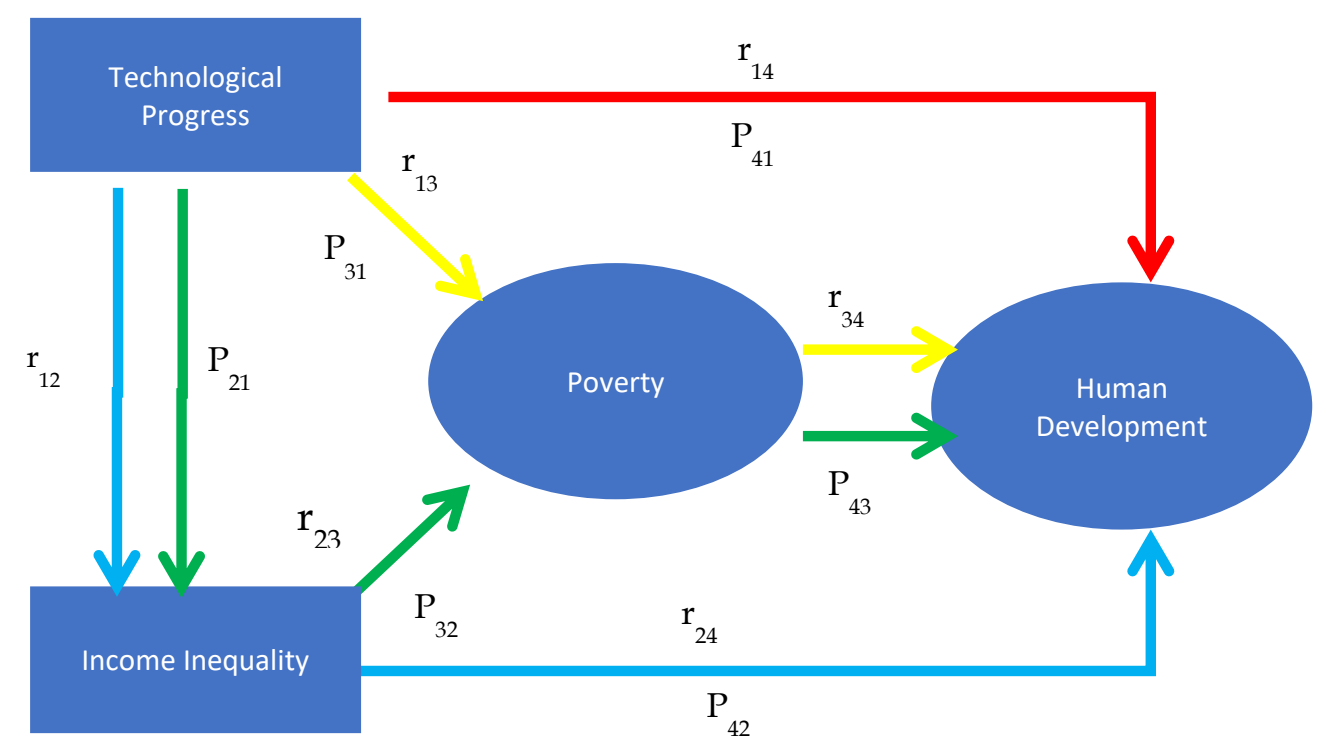

Figure 1 Impact Analysis of Technological Progress on Human Development Model. 
The path coefficient on Line-3 is calculated as a product of the multiplication of the path coefficients of the direct impact of technological progress on income inequality $\left(P_{21}\right)$ with the path coefficient of direct income inequality to poverty $\left(\mathrm{P}_{32}\right)$ and the path coefficient of direct poverty impacts on human development $\left(P_{43}\right)$. The indirect impact of technological progress on human development is analyzed through Path-4, where technological progress is thought to have an indirect impact on human development, through a variable between income inequality. The path coefficient on Line- 4 is calculated as the product of the coefficient of the direct impact of technological progress on income inequality $\left(P_{21}\right)$ with the path coefficient of the direct impact of income inequality on human development $\left(\mathrm{P}_{42}\right)$.

The path coefficient in the path analysis is calculated using the following path equations ${ }^{10}$ :

$$
\begin{aligned}
& r_{12}=P_{21} \\
& r_{13}=P_{31}+P_{32} r_{12} \\
& r_{23}=P_{31} r_{12}+P_{32} \\
& r_{14}=P_{41}+P_{42} r_{12}+P_{43} r_{13} \\
& r_{24}=P_{41} r_{12}+P_{42}+P_{43} r_{23} \\
& r_{34}=P_{41} r_{13}+P_{42} r_{23}+P_{43}
\end{aligned}
$$

There are 6 unknown things with 6 equations. Correlation coefficients $r_{14}, r_{24}, r_{34}, r_{13}, r_{23}$, and $r_{12}$ can be calculated if the technological progress data (TFP growth rate,\%), income inequality (gini index), poverty (percentage of poor people,\%) and available human development index. The path equation for calculating path coefficients can be completed simultaneously.

Data needed to test the direct impact and indirect impact of technological progress on human development, with poverty and income inequality as intermediate variables are: (1) TFP growth rate (\%) as an indicator of technological progress, (2) the gini index as an indicator of income inequality , (3) the percentage of poor people (\%) as indicators of poverty, and (4) the human development index as an indicator of human development.

Except for the TFP growth rate data, all data was obtained from the Central Statistics Agency in various publications. Sources of data on TFP were obtained from the BPPT research report (Agency for the Assessment and Application of Technology) which had conducted a series of studies on Technology and Economic Growth (Prihawantoro, et. Al., 2013). The data used is time series data from 2004-2013.

The effect of technological progress (as measured by the growth of the total factor productivity) on human index is said to be statistically meaning that if the path coefficient, $P_{i j}$, is greater or equal to 0.05 . Conversely, the effect is statistically meaningless if the path coefficient, $P_{i j}$, is smaller than 0.05 . This applies, both for decisions about direct influence and indirect influence.

${ }^{10}$ Source: http://faculty.cas.usf.edu/mbrannick/regression/Pathan.html 


\section{Result and Discussion}

Table 1 and Figure 2 present data on TFP growth (\%) as a measure of technological progress, the gini index as a measure of income inequality, the percentage of poor people (\%) as a measure of poverty and the human development index for Indonesia from 20042013. TFP growth in the Indonesian economy ranges from $-1.71 \%$ (2013) to $3.59 \%$ (2004). Meanwhile, the gini index ranges from 0.32 (2004) to 0.41 (2011, 2012, 2013). From the data, it can be seen the tendency that income inequality continues to worsen. The percentage of poor people has a declining trend, from $16.66 \%$ in $2004,15.97 \%$ in 2005 , up again to $17.75 \%$ in 2006 and subsequently continued to fall to $11.47 \%$ in 2013 . If you see the absolute number, this data may be misleading because with the population that continues to increase the number of poor people should also increase. The human development index shows a tendency to improve, 68.70 in 2004) to 73.81 in 2013.

Table 2 presents the correlation coefficients between each variable studied. The correlation between TFP growth and income inequality is negative, correlation coefficient, $r_{12}=-0.27$, and in the weak category. That is, an increase in TFP growth rate will reduce the level of income inequality, even though the relationship is in a weak category. While the correlation between TFP growth and poverty is also still in the weak category, but the relationship is positive. Correlation coefficient, $r_{13}=0.30$. That is, an increase in the TFP growth rate will increase the percentage of poor people. This relationship is not expected.

Table 1 TFP Growth, Gini Index, Percentage of Poor People and Human Development Index in Indonesia 2004-2013

\begin{tabular}{ccccc}
\hline Year & $\begin{array}{c}\text { TFP Growth(\%) } \\
(\mathrm{X} 1)\end{array}$ & $\begin{array}{c}\text { Gini Indeks } \\
(\mathrm{X} 2)\end{array}$ & $\begin{array}{c}\text { Percentage of Poor } \\
\text { People }(\%) \\
(\mathrm{X} 3)\end{array}$ & $\begin{array}{c}\text { Human Development } \\
\text { Index } \\
(\mathrm{X} 4)\end{array}$ \\
\hline 2004 & 3.59 & 0.32 & 16.66 & 68.70 \\
\hline 2005 & 3.26 & 0.36 & 15.97 & 69.57 \\
\hline 2006 & 1.78 & 0.33 & 17.75 & 70.10 \\
\hline 2007 & 1.52 & 0.36 & 16.58 & 71.17 \\
\hline 2008 & 1.94 & 0.35 & 15.42 & 71.76 \\
\hline 2009 & -1.57 & 0.37 & 14.15 & 72.27 \\
\hline 2010 & 1.49 & 0.38 & 13.33 & 72.77 \\
\hline 2011 & 2.86 & 0.41 & 12.36 & 73.29 \\
\hline 2012 & 3.22 & 0.41 & 11.66 & 73.81 \\
\hline 2013 & -1.71 & 0.41 & 11.47 & \\
\hline
\end{tabular}

Source: author (processed from several sources)

Table 2 Correlation Coefficient between TFP Growth, Gini Index, Percentage of Poor People and Human Development Index

\begin{tabular}{ccccc}
\hline $\begin{array}{c}\text { Correlation } \\
\text { Coefficient }\end{array}$ & $r 1$ & $r 2$ & $r 3$ & $r 4$ \\
\hline$r 1$ & 1.00 & & & \\
$r 2$ & -0.27 & 1.00 & & \\
$r 3$ & 0.30 & -0.94 & 1.00 & 1.00 \\
\hline r3 & -0.46 & 0.92 & -0.92 & \\
\hline
\end{tabular}

Source: Data Processing Results, 2016 


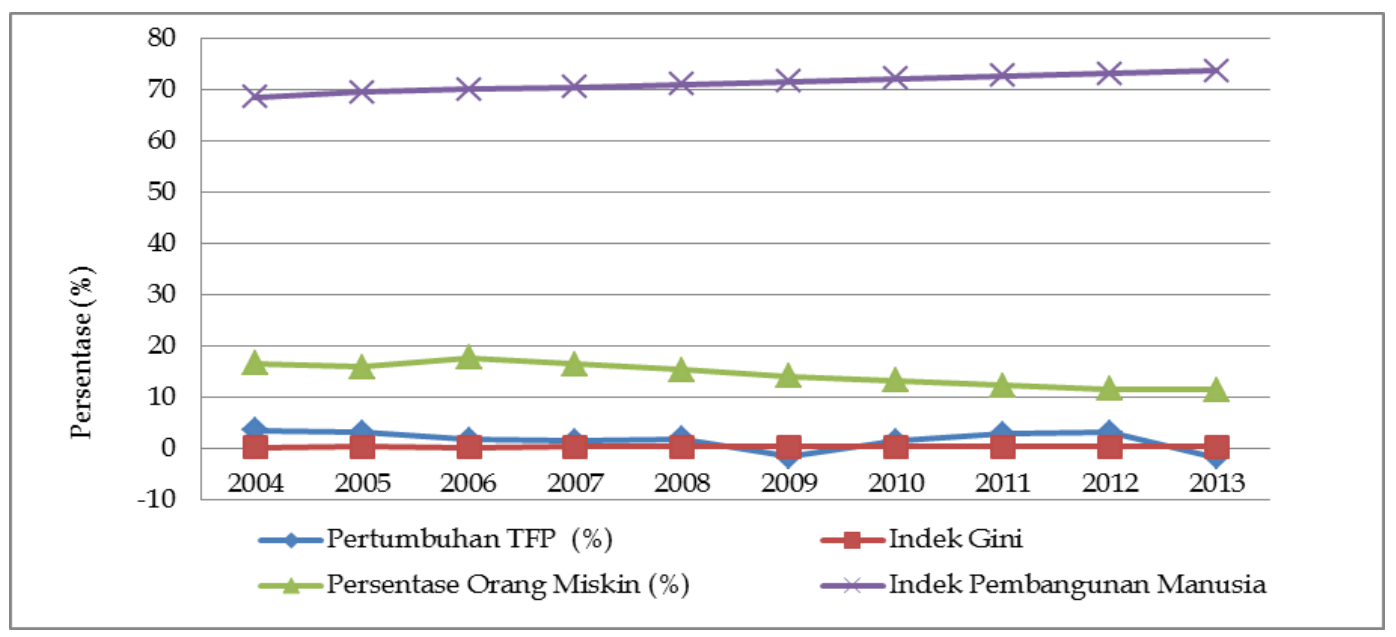

Figure 2 TFP Growth, Gini Index, Percentage of Poor People and Human Development Index in Indonesia 2004-2013

Technology should be able to overcome the problem of poverty. Not even adding to the poor. More unpleasantly, the relationship between TFP growth and the human development index is negative and in the moderate category, with a correlation coefficient, $r_{14}=-0.46$. That is, the TFP growth rate will be related to the decline in the human development index.

The correlation between income inequality and poverty in the category is very strong and is negative, with a correlation coefficient, $r_{23}=-0.94$. That is, the more unequal income of the community the lower the percentage of poor people. The analogy is that the more evenly distributed the income of the people, the poorer people are. This conclusion is quite "dangerous" because to reduce poverty, people's income must be made lame. While the relationship between income inequality and human development in the category is very strong and positive, with a correlation coefficient, $r_{24}=0.92$. That is, income inequality has a very strong positive correlation with the human development index. The more unequal income of the community the higher the human development index. This is also "danger". Should efforts to "build humanity" be achieved by increasingly making unequal income for the community?

Finally, the correlation between poverty and human development is negative in the very strong category, with the correlation coefficient $r_{34}=-0.92$. The percentage of poor people is negatively correlated with human development. Increasing the percentage of poor people will reduce the human development index. Presumably this is in accordance with the theory considering that one of the indicators of human development is people's purchasing power. The higher the purchasing power, the higher the human development index.

Figure 3 presents the results of the calculation of path coefficients based on equations (1) to (6) which are based on the correlation coefficients between variables of technological progress, income inequality, poverty and human development. Path coefficient on Line- 
1 , with $\mathrm{P}_{41}=-0.17$. That is, directly technological progress has a negative impact on human development. An increase in the TFP growth rate will reduce the human development index. This direct impact is statistically significant; means because $P_{41}>0.05$.

Indirectly, technological advances also negatively affect human development, through poverty variables, namely through Path-2: $\mathrm{P}_{43} \times \mathrm{P}_{31}$. Technological advances have a positive effect on the percentage of poor people $\left(\mathrm{P}_{31}\right)$ and the percentage of poor people has a negative influence on human development. Indirectly, technological progress has a negative effect on human development, through poverty, through Path-2: $\mathrm{P}_{43} \times \mathrm{P}_{31}$. Technological advances have a positive effect on poverty and poverty negatively affecting human development. An increase in the percentage rate of TFP indirectly has a negative effect on the human development index. The higher the percentage increase in TFP the lower the human development index. Through $\mathrm{P}_{43}-\mathrm{P}_{31}$, an increase in TFP rate will increase the percentage of poor people, while the increase in the percentage of poor people will reduce the human development index. Fortunately, this negative indirect effect is not statistically significant because Path-2: $\mathrm{P}_{43} \mathrm{X} \mathrm{P}_{31}=-0.002<0.05$.

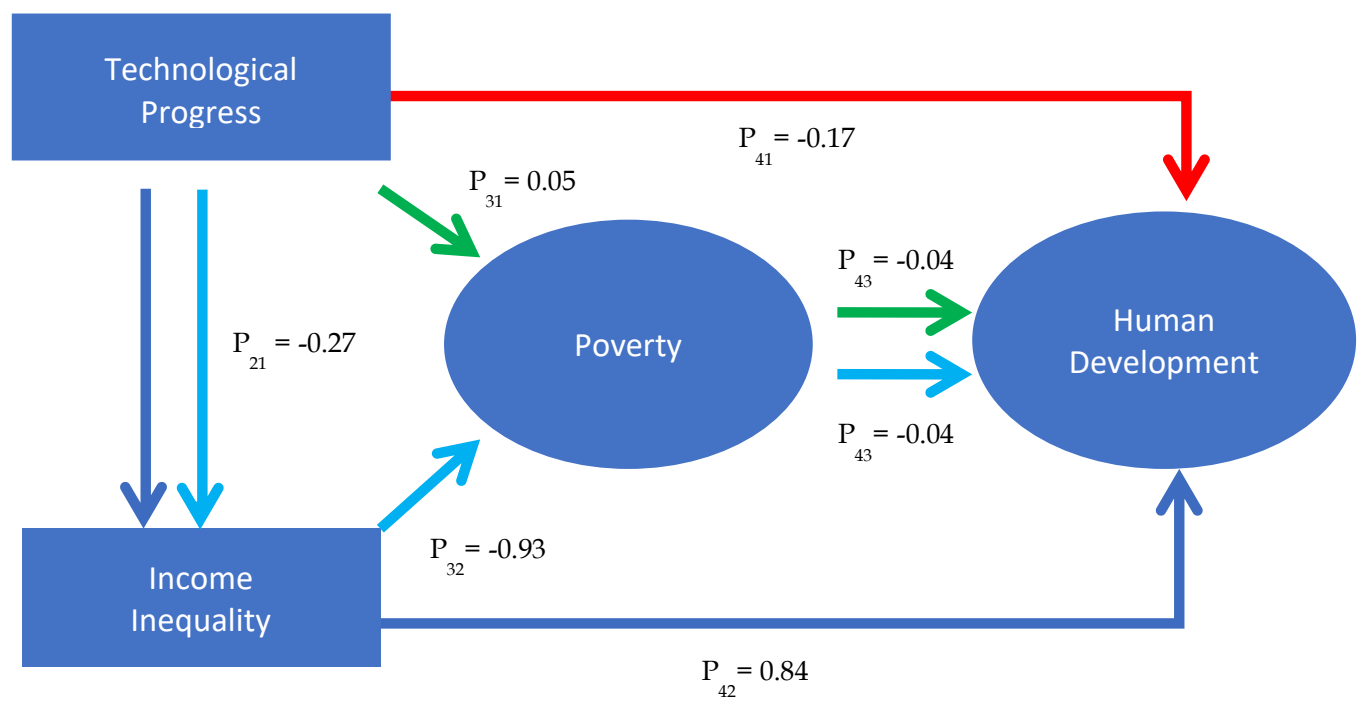

Figure 3 Path coefficients on each line: Path-1, Path-2, Path-3 and Path-4

Indirectly, technological progress has a negative effect on human development, through variables of poverty and income inequality through Path-3: $\mathrm{P}_{43} \times \mathrm{P}_{32} \times \mathrm{P}_{21}$. Technological progress has a negative effect on income inequality $\left(P_{21}\right)$, while income inequality has a negative effect on poverty $\left(\mathrm{P}_{32}\right)$ and poverty alleviation has a negative effect on human development $\left(\mathrm{P}_{43}\right)$. An increase in the percentage rate of TFP indirectly has a negative effect on the human development index. The higher the percentage increase in TFP the lower the human development index. Through the $\mathrm{P}_{43}-\mathrm{P}_{32}-\mathrm{P}_{21}$ path, the increase in the TFP rate will reduce income inequality (income is more evenly distributed), further decreasing income inequality will increase the percentage of poor people and the increase in income of the poor will reduce the human development index. Fortunately, this 
negative indirect influence is not statistically significant because Path-3: $\mathrm{P}_{43} \times \mathrm{P}_{32} \times \mathrm{P}_{21}=-$ $0.01<0.05$.

Indirectly, technological changes have a positive effect on human development, through income inequality variables; via Line- 4 : $P_{42} \times P_{21}$. Technology changes have a negative effect on income inequality, while income inequality has a negative effect on human development. An increase in the percentage rate of TFP indirectly has a negative effect on the human development index. The higher the percentage increase in TFP the lower the human development index. Through the $\mathrm{P}_{43}-\mathrm{P}_{32^{-}} \mathrm{P}_{21}$ line, the increase in the TFP rate will reduce income inequality (income is more evenly distributed), further decreasing income inequality increases the human development index. This negative indirect effect is statistically significant because Path- $4: P_{42} \times P_{21}=-0.22>0.05$.

\section{Conclusion}

From the results of the analysis it can be concluded that directly and indirectly, technological progress has a negative effect on human development. The higher the TFP rate the smaller the human development index. Directly, through Path-1 with $\mathrm{P}_{41}$ path coefficients, technological progress has a negative effect on human development. The higher the TFP rate the smaller the human development index.

Indirectly, technological progress has a negative effect on human development in all paths that are traversed. Through Path-2 $\left(\mathrm{P}_{43}-\mathrm{P}_{31}\right)$, technological progress has a negative effect on human development, through poverty variables. Through Path-3 $\left(P_{43}-P_{32}-P_{21}\right)$, technological progress has a negative effect on human development, through variables of poverty and income inequality. Through Path-4 $\left(\mathrm{P}_{42}-\mathrm{P}_{21}\right)$, technological progress has a negative effect on human development, through income inequality variables.

\section{References}

Anonymous. (2011). Poverty and Inequality. Analysis. Retrieved from:

Anonymous. (2015). What is Human Development? Retrieved from: http://hdr.undp.org/en/content/what-human-development.

Anonymous. (2016b). Indicators of Poverty \& Hunger. United Nations. Retrieved from: https://www.un.org/en/

Badan Pusat Statistik. (2014a). Indeks Pembangunan Manusia Menurut Provinsi 1996-2013. Jakarta: Badan Pusat Statistik. Retrieved from: http://bps.go.id/pembangunan manusia

Badan Pusat Statistik. (2014b).Jumlah Penduduk Miskin, Presentase Penduduk Miskin dan Garis Kemiskinan 1970-2013. Jakarta: Badan Pusat Statistik. Retrieved from: http://bps.go.id/kemiskinan

Badan Pusat Statistik. (2016a). Gini Ratio Indonesia, 1996 - 2015. Jakarta: Badan Pusat Statistik. Retrieved from: $\quad$ http://data.go.id/dataset/0334f306-b377-43b3-813f0c631c75ed15/resource/105e9922-f4b3-4a92-bb7c- 
Bjork, G. J. (1999). The Way It Worked and Why It Won't: Structural Change and the Slowdown of U.S. Economic Growth. Westport, CT; London: Praeger.

Davies, A. \& Quinlivan, G. (2006). A Panel Data Analysis of the Impact of Trade on Human Development. Journal of Socio-economics, 35(5): 868-876. https://doi.org/10.1016/j.socec.2005.11.048

Dodge, Y. (2003). The Oxford Dictionary of Statistical Terms. OUP.

Field, A. J. (2008). Productivity. In David R. Henderson. Concise Encyclopaedia of Economics (2nd edition). Indianapolis: Library of Economics and Liberty.

Glaeser, E. L. (2005). Inequality. SSRN Electronic Journal. https://doi.org/10.2139/ssrn.832653

Hicks, J. R. (1963). The Theory of Wages. London: Palgrave Macmillan. https://doi.org/10.1007/978-1-349-00189-7.

Muchdie, M. (2016). The Impact of Technological Change on Poverty Alleviation in Indonesia. Paper submitted to International Multidisciplinary Conference, Universitas Muhammadiyah Jakarta.

OECD \& ADB. (2002). Technology and Poverty Reduction in Asia and the Pacific. Development Centre Seminars. https://doi.org/10.1787/9789264176171-en

Prihawantoro, S., Suryawijaya, I., Hutapea, R., Sugarmansyah, U., Alkadri, Rusiawan, W., \& Permana, M. Y. (2013). Peranan Teknologi dalam Pertumbuhan Ekonomi Indonesia. Jakarta: Badan Pengkajian dan Penerapan Teknologi.

Ricardo, S (2008). The Impact of Lifelong Learning on Poverty Reduction. IFLL Public Value Paper 1. Latimer Trend, Plymouth, UK.

Srinivasan, T. N. (1994). Human Development: A New Paradigm or Reinvention of the Wheel?. Human Development 84(2), 238-243.

Streeten, P. (1994). Human Development: Means and Ends. Human Development 84(2), 232 237.

Suharto, E. (2009). Membangun Masyarakat Memberdayakan Rakyat, Kajian Strategis Pembangunan Kesejabteraan social dan Pekerjaan Sosial. 3Ed. Bandung: PT Rafika Aditama

Suparlan P. (1984). Kemiskinan Kota. Jakarta: Sinar Harapan.

Suryahadi, A., Yumna, A., Raya, U. R., \& Marbun, D. (2010). Review of Government's Poverty Reduction Strategies, Policies and Programs in Indonesia. Research Report, Jakarta: The SMERU Research Institute.

Todaro, M. P. \& Smith, S. C. (2002). Economic Development. Boston: Addison Wesley Publishing Company.

United Nations Development Programme (1997). Human Development Report 1997. Human Development Report.

Wodon T.Q., \& S. Yitzhaki. (2002). Inequalityand Social Welfare. In J. Klugman, (editor). Poverty Reduction Strategies Sourcebook. Washington DC: World Bank.

Wright, S. (1921). Correlation and Causation. Journal Agricultural Research. 20, 557-585.

Wright, S. (1934). The Method of Path Coefficients. Annals of Mathematical Statistics, 5(3), 161 215. https://doi.org/10.1214/aoms/1177732676 